\title{
Perfusion alterna in Takayasu arteritis
}

Figure CT perfusion map revealing alternating hyper- and hypoperfusion
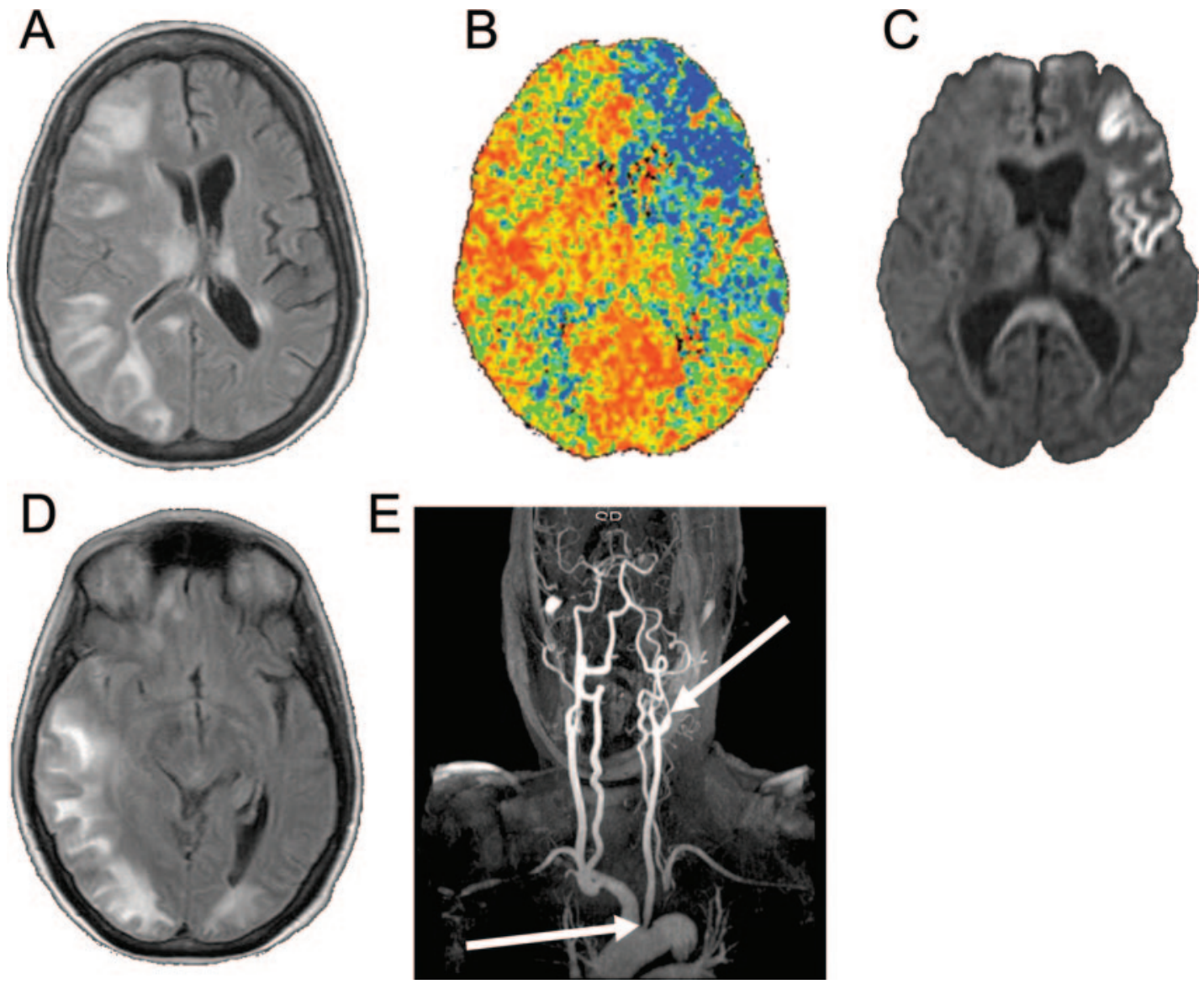

FLAIR sequences reveal right cerebral (A) and left occipital (D) swelling with midline shift. CT perfusion map shows right cerebral hyperperfusion and left frontal hypoperfusion (B). Axial DWI 3 weeks later shows left frontal cerebral infarction (C). The MRA (same day as A) demonstrates absent left internal carotid arterial flow due to proximal stenosis ( $E$, arrows).

A 48-year-old woman with Takayasu arteritis had a worsening headache and left limb weakness. Blood pressure measured 150/75 mm Hg from the right arm. Brain MRI showed right cerebral and bioccipital swelling ( figure, A, D). The MRA revealed proximal left common carotid artery and ipsilateral internal carotid artery stenosis ( figure, E) and the CT perfusion map revealed alternating hyperperfusion on the right hemisphere and hypoperfusion on the left ( figure, B). Controlled blood pressure lowering over the next several days resulted in complete recovery. Two weeks later following an emergent abdominal surgery that was complicated by transient hypotension to 100/65 mm Hg, she developed expressive aphasia with right hemiparesis ( figure, C). Left carotid stenosis protected from effects of high systolic pressure, yet predisposed to an ischemic stroke from blood pressure lowering.

Gregory Youngnam Chang, MD, FAAN, Orange, $C A$

Disclosure: The author reports no disclosures.

Address correspondence and reprint requests to Dr. Gregory Youngnam Chang, Department. of Neurology, Bldg. 55, Rm. 121, 101 The City Drive, South, Orange, CA 92868; gychang@uci.edu 


\title{
Neurology
}

\author{
Perfusion alterna in Takayasu arteritis \\ Gregory Youngnam Chang \\ Neurology 2008;71;614 \\ DOI 10.1212/01.wnl.0000323933.15055.0c
}

This information is current as of August 18, 2008

\section{Updated Information \& Services}

\section{Citations}

\section{Subspecialty Collections}

Permissions \& Licensing

\section{Reprints}

including high resolution figures, can be found at: http://n.neurology.org/content/71/8/614.full

This article has been cited by 1 HighWire-hosted articles: http://n.neurology.org/content/71/8/614.full\#\#otherarticles

This article, along with others on similar topics, appears in the following collection(s):

All Cerebrovascular disease/Stroke

http://n.neurology.org/cgi/collection/all_cerebrovascular_disease_strok e

Critical care

http://n.neurology.org/cgi/collection/critical_care

MRI

http://n.neurology.org/cgi/collection/mri

Stroke in young adults

http://n.neurology.org/cgi/collection/stroke_in_young_adults

Stroke prevention

http://n.neurology.org/cgi/collection/stroke_prevention

Information about reproducing this article in parts (figures,tables) or in its entirety can be found online at:

http://www.neurology.org/about/about_the_journal\#permissions

Information about ordering reprints can be found online:

http://n.neurology.org/subscribers/advertise

Neurology ${ }^{\circledR}$ is the official journal of the American Academy of Neurology. Published continuously since 1951, it is now a weekly with 48 issues per year. Copyright. All rights reserved. Print ISSN: 0028-3878. Online ISSN: 1526-632X.

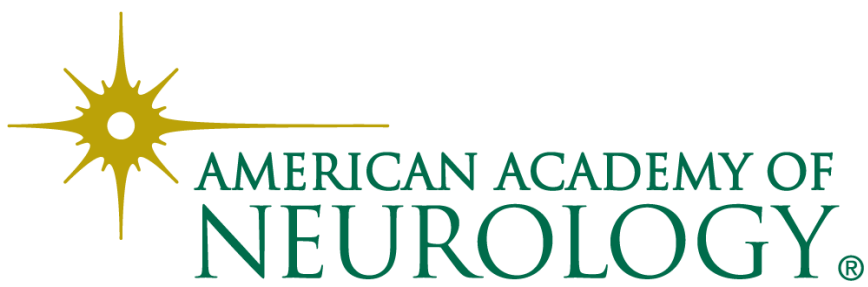

